\title{
Invited Paper - Engineering for the Americas (EftA)
}

\section{Dr. Reginald Vachon P.E., American Society of Mechanical Engineers}

Dr. Vachon, an engineer with a physics background and business executive, has served in the US Army and was a chaired professor of mechanical engineering. He received his education at the US Naval Academy, Auburn University, Oklahoma State University and Jones Law School. He was the Chair of the American Association of Engineering Societies and is Vice President for North America for Pan American Union of Engineering Organizations (UPADI). He serves on the WFEO committee on relations with the UN. Dr. Vachon has authored over 150 papers, numerous technical reports and presented papers internationally. He is a member of the Pan American Academy of Engineering and the International Nuclear Energy Academy. He served on the Department of Homeland Security Science and Technology Advisory Committee for seven years. He has served as the advisor to the President of the World Federation of Engineering Organizations. Recently he was on the AIAA Structures Committee of Standards that developed Standard, S -1110-2005 Space Systems-Structures, Structural Components , and Structural Assemblies. He is an original patentee for digital image correlation and co-holds a number of other patents encompassing the DMI optical strain technology. He served as President of the American Society of Mechanical Engineering. He is a licensed attorney and admitted to practice before the US Supreme Court. He has international project experience in Venezuela, Honduras, Nicaragua, Brazil, Russia, Saudi Arabia, Sudan, Iran, Egypt, Indonesia, Hong Kong, Cameroon and Belize, He has conducted research and development projects with the US Army, US Navy. NASA ,DoD, EPA, ERDA (predecessor to DOE), DOE, NSF and other agencies, as well as with industrial clients such as IBM, Northrop Grumman, Lockheed Martin, Polish Air Force Institute of Technology, RUAG, Halliburton and others. He was the president of the engineering firm that was the Resident Engineer and Constructor for the DOE Strategic Petroleum Reserve. He conducted an NSF Chautauqua series on solar energy design. His research areas cover bioengineering, energy, mechanics, hypersonic aerodynamics, space power and systems engineering He is a Honorary Member ASME, Fellow IMehE, Fellow ASCE, Life Member ASEE, Assoc. Fellow AIAA , Fellow NSPE, Member IEEE . Fellow Hong Kong Institution of Engineers, Fellow Institution of Engineers Singapore, member Sigma Xi and Phi Kappa Phi. He is a registered engineer in several states and a licensed European Engineer through FEANI.

\section{Dr. Robert O. Warrington Jr., Michigan Technological University}

Robert O. Warrington is currently Director of the Institute for Leadership and Innovation, which houses the highly interdisciplinary and innovative Enterprise program, the High School Enterprise program and the Pavlis Institute for Global Technological Leadership at Michigan Technological University. Dr. Warrington was Dean of the College of Engineering from 1996 to 2007 and was the founder and Director of the Institute for Micromanufacturing at Louisiana Tech University. Before joining Michigan Tech in 1996, he received his BS degree in Aerospace Engineering from Virginia Polytechnic Institute, his MS in Mechanical Engineering from the University of Texas at El Paso and his $\mathrm{PhD}$ in Mechanical Engineering from Montana State University. Dr. Warrington served in the US Army for two years and on the faculty at Montana State University for eight years. He was the head of the Mechanical and Industrial Engineering Department at Louisiana Tech University for 11 years, and was the Director of the Institute for Micromanufacturing from 1991-1996. Dr. Warrington was a founding advisory board member for the ASME Nanotechnology Institute. He is past VP for Education, Centers Sector of ASME. He currently leads the Vision 2030 study for the future of mechanical engineering education. He was a member of the Board of Directors for ABET after serving a number of years as a program evaluator, member of the Engineering Accreditation Council and the Executive Committee of the EAC. Dr. Warrington is chair of the Education Committee for the Pan American Federation of Engineering Societies (UPADI). Dr. Warrington is a Fellow of ASME and AAAS and is a member of the Pan American Academy of Engineering. He was an associate editor (now emeritus) for the ASME/IEEE Journal of Microelectromechanical Systems and has over 150 technical publications and numerous presentations (35 invited), and 49 research grants from foundations, government and industry. Dr. Warrington is the founder of the Commercialization of 
Microsystems Conferences, is a past founding president of MANCEF and currently is a member of the executive board for MANCEF. Dr. Warrington was an Associate Director for the Center for Wireless Integrated Microsystems, an NSF Engineering Research Center (2000-10). Dr. Warrington's research interests include MEMS (particularly micro heat transfer and fluid flow), micromanufacturing, energy scavenging at the microscale, and micromechanical machining processes.

\section{Dr. Robert D. Kersten, University of Central Florida}

\section{Dr. Robert D. Kersten, Ph.D.,P.E., D.WRE, Dist. M. ASCE}

Dean and Professor Emeritus, University of Central Florida.Founding Dean UCF College of Engineering. A native of Illinois, received B.S. and M.S. degrees from Oklahoma State University, and the Ph.D. from Northwestern University. Fellow status in AAAS, ABET, NSPE, ASCE \& FES. Member eight cademic Honor Societies, named to five national Who's Who registers. Former Chair EAC/ABET, Florida Board of Professional Engineers, Governor Appointee to two energy task forces, former member of Mid-Florida Economic Development Commission. Industrial experience Includes Flight Safety Foundation, ExxonMobil, Dept. of the Interior, and A.E. Staley Manufacturing Co. Author of over 80 papers and five books ranging over a wide variety of professional interests. Named to many honors and awards, including ASEE Centennial Medallion, Distinguished Member of ASCE, UPADI Golden Vector, and elected to Pan American Academy of Engineering. Currently serves on AAES Intac Committee on UPADI. 


\section{ENGINEERING FOR THE AMERICAS (EftA)}

\section{PROLOGUE}

\section{INTRODUCTION}

Engineering for the Americas (EftA) was initiated at the meeting of the Ministers and High Authorities of Science and Technology of the Organization of American States meeting in Lima in November 2004. The stated purpose of EftA is "Fostering Growth through Quality Engineering" Each subsequent meeting of the Ministers has emphasized EftA. This prologue provides the context for a thoughtful White Paper on EftA prepared by members of the Committee on Engineering Education of the Pan American Union of Engineering Associations (UPADI).

\section{FOCUS AREAS}

Educational Innovation: To encourage the innovation and reform of engineering education and the implementation of new educational techniques that involve the productive sector as a key partner, motivator and collaborator in shaping educational improvements and activities that are relevant to market needs as well as foster a culture of life long learning.

Accreditation, Quality Assurance and Mobility: To foster activities leading to an understanding to the importance, establishment or enhancement of quality assurance, methods of accreditation, and integration of national, regional and hemispheric systems.

Job Creation: To engage with Industry to create an ongoing real world experience for students, stimulate employment through internships and coops, and drive a sustained Industry / Academia interaction around producing appropriate outcomes.

\section{TRANSLATION}

EftA's purpose is to promote economic and social development through quality engineering education for innovation and hemispheric collaboration in job creation is concentrated on education. Efta's purpose is translated into action through an Advisory Committee and the following organizations: Latin American Consortium of Engineering Institutions (LACCEI), Pan American Federation of Engineering Societies (UAPDI) and Pan American Academy of Engineering (API). Dr. Jorge Duran, Chief ,Science, Technology, and Innovation Department of Economic Development Trade and tourism Organization of American States, is the focal point for EftA. LACCEI and UPADI have education committees. Both hold and participate in meetings of educators form the Americas. There is cooperation between, LACCEI, UPADI and API. In addition representatives of these organizations meet with Ministers. The most recent meeting in Washington was held in December 2012 where the three organizations presented unified presences.

\section{MINISTERS' WORKING GROUPS}

The OAS Ministers at the Panama meeting in 2011 created four working groups. The EFTA activities in education come under Working Group 2. Human resources training and education. This working group is chaired by Argentina. The Ministers stated that Working Group 2 will work to help increase the number of female and male graduates in science, technology, engineering, and technical education, and to improve study programs in these areas to respond to the changing needs of industry, especially MSMEs, and communities. It will also work to: 
a. Enlist universities, to upgrade study programs in science, technology and engineering so as to graduate a critical mass of qualified men and women in strategic industries and fields, emphasizing multi-disciplinary approaches, strengthening private-sector linkages in line with to the social and economic situation of their countries;

b. Promote the strengthening of science, technology, engineering and mathematics (STEM) education in primary and secondary schools;

c. Encourage opinion surveys among secondary school students on science and scientific professions.

d. Define the theme and supervise the development of a case study and/or project for the sharing of best practices and experiences in the region and make recommendations to COMCYT to take action;

e. Promote the continued professional development of faculty members in their fields and periodic training on the latest teaching and research methods;

f. Promote the exchange of students in the Hemisphere taking into account gender equity and greater participation of minorities;

g. Facilitate hemispheric cooperation mechanisms so that member states collaborate in their efforts to upgrade and maintain their science, technology, and engineering study programs;

h. Facilitate information sharing pertaining to academic mobility for students and professionals among OAS member states;

i. Create and/or strengthen extension services and technology transfer based on voluntary and mutually agreeable terms to the community and industry, especially MSMEs;

j. Design and coordinate regional and hemispheric projects and develop academia-publicprivate partnerships in the above-mentioned topics, reinforcing particularly the "Engineering for the Americas" hemispheric initiative, approved at the First Meeting of Ministers and High Authorities of Science and Technology and endorsed by the Second Meeting;

\section{WORKING GROUP AND RELATED MEETINGS IN 2013}

Working Group 2 is convening in Argentina In mid June 2013.

UPADI is conducting an engineering education workshop in Medellin August 19-23 which is a follow-up to an April 2012 education meeting in Havana. .

LACCEI will hold an Innovation in Engineering Technology and Education for Competiveness and Prosperity in Cancun 14-16 August 2013

These meetings are directed toward unifying the professionals in engineering to promote the welfare of the Americas through practitioners and teachers of engineering and those who prepare students to enter engineering programs.. This prologue is followed by a WHITE PAPER that discusses EftA thinking 


\title{
ENGINEERING FOR THE AMERICAS -WHITE PAPER
}

\author{
(Implications for Engineering Education, Social and Economic Development)
}

\begin{abstract}
The intense movement toward globalization of the marketplace and the internationalization of many human activities is widely recognized. Partnerships among many stakeholders are becoming more and more the norm. The twin driving forces of "free trade" and "national expectations" are becoming self-evident. As a result there are many associated education and quality assurance issues. The Engineering for the Americas (EftA) group has assembled a significant partnership between industry, government, academe and professional associations dedicated to achieving global leadership and making economic impacts through enhancing engineering education globally, as well as throughout the Western Hemisphere. Engineering schools must be at the forefront of sustainable education for a sustainable future [34]. We must prepare those who will 'practice and carry on' to be the leaders, innovators, and entrepreneurs our countries so desperately need.
\end{abstract}

\section{Introduction}

Engineering for the Americas (EftA) represents a shared belief that engineers and scientists are the people who stand ready to enable the economies of the Americas to compete in the global marketplace. If we can encourage investments in effective systems of education through education reform, by quality assurance and accreditation, global integration through harmonization of degrees, the result will be enhanced workforce capabilities allowing mobility of work and persons. Such educational change will serve to develop human capital and impact national competitiveness. Stimulated by the globalization of the engineering profession and the industries that it supports, and driven by increased interest in trade between countries and regions in the American Hemisphere, a grass-roots movement to enhance engineering and technology education in the hemisphere has been gathering momentum through discussions at conferences over the past six years $[14,38]$. The engineering and scientific communities of the Americas have come to the realization that they have to articulate a vision for the future. This must be a vision that enables them to take their rightful place among global engineering communities. Science, Technology and Engineering are globally ubiquitous [32].

A group of representatives from industry, academia, government, and professional associations, has met periodically over the past six years to implement a concept of a Western Hemisphere Partnership. In addition the first meeting of Ministers and High Authorities of Science and Technology acting within the framework of the Inter-American Council for Integral 
Development (CIDI) of the Organization of American States (OAS). This assembly which took place in Lima, Peru in 12 November 2004 adopted the Declaration of Lima. Subsequently, the Office of Education, Science and Technology (OEST) of the OAS [1] in response to the Declaration and with the assistance of several major industrial partners sponsored the "Engineering for the Americas Symposium" on Capacity Building for Job Creation and Hemispheric Competitiveness," in Lima, Peru 29 November-December 2, 2005. The outgrowth of these efforts and subsequent meetings of the Ministers in Mexico (2008) and Panama (2011) is the current mandate for the OAS Division of Science and Technology to aggressively address the development of the Engineering for the Americas concept [21, 23]. Continuing efforts by the Ministers now includes the EftA concept in the current working groups of Plan Panama.

A nation can expect to become successful today only if it strives to create a meritocracy, in which positions of leadership and responsibility are distributed to the most outstanding individuals, irrespective of social class or personal connections [2]. "The skills, ingenuity, training and expertise of the human capital that is developed will determine the long-term prosperity of the economy, and indeed will determine the long-term prosperity of the world" [36].

\section{Overarching Goal}

The overarching goal of Engineering for the Americas is to build engineering capacity, based on quality education that creates workforce capabilities for the solution of local needs and that opens the way for the Americas to more effectively compete in today's global economy.

\section{EftA Vision}

Engineering for the Americas will provide global leadership and achieve economic impact through development of the hemisphere's engineers. A revitalized, holistic and multidimensional engineering experience that is recognized as meaningful and portable that will enable the hemisphere's engineers to develop relevant skills and to excel in facing the challenges of the twenty-first century.

\section{EftA Mission}

EftA seeks to build capacity of engineering talent in the Americas and to improve regional innovative capacity and competitiveness. It contributes to creating holistic and entrepreneurial skills in engineering, enabling mobility, and fosters partnership between industry, government, academia and professional associations to achieve both economic and social impacts. 


\section{EftA Key Strategies}

The key strategies of EftA are (1) Educational Innovation, (2) Quality Assurance and Accreditation, and (3) Job Creation (through innovation and entrepreneurship). These strategies will engage complementary organizations over time to enhance offerings, performance, and impact of all stakeholder and partner organizations.

\section{Internationalization}

Internationalization of nearly every world activity is bringing intense pressure for change. The multiplicity of free trade negotiations following the Uruguay and Doha Rounds of World Trade Organization (WTO) negotiations, implementation and development cover a maze of subject areas (i.e. twenty according to the agenda of the Doha Round). Nearly all of these disciplines involve some engineering in one-way or another [18]. In particular the disciplines of trade involving Agriculture, Services (including Engineering Services), Intellectual Property Rights, Market Access of non-agricultural products, WTO Rules, Environment, Electronic Commerce, Trade and Technology Transfer, Technical Cooperation and Capacity Building, etc. remain at the forefront of most discussions. The UN Millennium Goals [51] may be analyzed in a similar fashion.

The Americas are one of the most economically diverse regions and present a puzzle. Countries range from the relatively hyper-wealthy United States and developing powerhouse Brazil to the small island economies of the Caribbean. Several nations are relatively poor. The average population for each country is 30 million people. The overall regional population is 871 million, second only to Asia on both counts. With the world's lowest average unemployment rate and peaceful relationships, it would seem poised for broadly shared economic success. The reality is that many of the economies appear to be stagnating. However, on a population-weighted basis income per capita is higher than any other region, even Europe. Countries in the Americas perform better than the world average in eight of 10 economic freedom areas [19]. However, corruption and inflation are problem areas.

Competition in almost every sphere has an engineering component. In short "being good is not good enough, we must compete in a globalized economy [6]". To do so requires the very best of the entire workforce of every nation. Since engineering professionals are the key element in the workforce, they must assume a leadership role in this competitive quest for success in the global marketplace. 
In the context in which we now live, e.g. internationalization, rising expectations, capacity building, sustainable development, policy work [46], increasing ethical concerns, quality focus and cultural literacy, require greater participation of the engineering profession. To compete on the global stage, attract investment, establish first-rate centers of research, and fully develop production facilities in many countries of the hemisphere requires collaboration of many stakeholders. In short, we must recognize that a knowledge society rests on a foundation of educational and research excellence [56].

\section{Quality Assurance/Accreditation: The Platform for Mobility}

Implementation of free trade agreements demands mutual recognition of educational qualifications of many professional groups, including engineering. It becomes axiomatic that we are concerned with "international standards not just national standards [11]." Differing educational systems among the many nations means some form of quality assurance process must be applied to the professional programs in higher education, including the engineering education enterprise [48]. The trend appears to be replacement of government agencies with professional peer review systems. An extensive formation process will of necessity be required to meet the many demands being imposed, ranging from preparation for professional practice [19] to general capacity building [15] in some cases. A UNESCO report [24] shows that per capita gross domestic product increases as a function of increased time spent in secondary school and higher education. Similarly, a World Bank study [55] indicates that good quality tertiary education promotes economic vitality.

The demand, indeed the appetite, for higher performance standards in every sector is expanding. Engineers are expected to foster progress toward a daunting array of ends-creating new knowledge, artifacts, and systems; stimulating social and economic development; creating wealth and jobs; sharpening the competitive edge; raising prospects for more satisfying lives; caring for the environment; and providing for national security---(paraphrased from Bordogna [4]). It is clear that engineers enable nations to perform in a competitive manner and we must insist on doing our best. Science, Technology and Engineering power national and global economies, influence international relations, and are indispensable for addressing regional and global challenges [32]. The continuing transformation of the engineering education process remains a very complex activity, but one worthy of the effort if we are to achieve some consensus leading to the shaping of international standards [26]. Integration into the world economic community will require an engineering workforce educated to international standards [3]. Education is the foundation of our modern knowledge society. 
Without quality assurance systems there can be no mutual recognition of qualifications and hence little likelihood of readily acceptable cross-border practice of any of the licensed professions, including engineering. There is little doubt that engineering is the key that enables a nation's capacity to perform. Most authorities would agree that the Latin America and Caribbean area have some Schools of Engineering reaching world class level, but the overall average is still of low quality. Quality Assurance systems are the 'driving force' for continuing quality improvement. Many institutions throughout the world are seeking to emulate the frontier research, cutting-edge tools, and skill sets that characterize world-class engineering schools. Accreditation is the key. It behooves us to develop regional systems that assist all to achieve higher educational standards.

\section{Current Status of Accreditation System Development}

\section{Introduction}

The current roster of the United Nations (UN) lists a membership of 192 nations. Of these, 139 are members of the World Trade Organization (WTO). Clearly, the WTO provisos regarding cross border practice of licensed professions have as a prerequisite the existence of some form of higher engineering education that leads to the formation of qualified practitioners. In turn, cooperation among nations largely depends on the existence of quality assurance systems. Competent licensing authorities in assessing the educational and experiential qualifications of practitioners must rely on such quality assurance mechanisms. The establishment of benchmarks regarding the qualifications of engineers educated in the several countries is of prime importance. External quality assurance has become the most important issue on the policy agenda of higher education systems across the world.

Given the many disparities in educational systems, lack of agreement on any common body of knowledge, and wide variations in evaluation and accreditation systems the further development of quality assurance systems becomes of the first order importance. Clearly, there is an opportunity to achieve agreement on appropriate attributes essential to the formation of engineering graduates and the necessary metrics to measure and confirm them. It should be noted here that we are here mostly concerned with programmatic accreditation as opposed to institutional accreditation $[19,20]$. The current status of this activity in the Western Hemisphere follows:

\section{North America}

The three nations of the North American continent have led the world in this area of professional activity. In the United States (U.S) ABET, Inc. (representing 32 professional and technical 
societies) has been in operation for nearly 75 years [29]. The Canadian Council of Professional Engineers (CCPE) (now referred to as Engineers Canada) has had a comparable system for nearly 40 years [45]. In Mexico, the Consejo de Acreditacion de la Ensenanza de la Ingenieria (CACEI), an arm of the Ministry of Education, has been in operation for about 15 years [28]. These three entities have frequently been called upon by other national entities for assistance in accreditation system development. They have mutually agreed to the formation of the Western Hemisphere Partnership (now identified with the Engineering for the Americas) with the objective of assisting nations of the Western Hemisphere in the development of national and/or regional systems of accreditation [49] and capacity building in critical systems of human resources.

\section{Central America}

The seven nations of this region are cooperating in a major project (partially sponsored by UNESCO and the Inter-American Development Bank) to develop a regional system of accreditation [25]. This project represents the Network of Central American Faculties and Institutions of Engineering (REDICA) of 16 public universities in seven nations. Action was initiated in 1998 during a workshop hosted by the Universidad de San Carlos in Guatemala. The workshop included representatives of Belize, Costa Rica, El Salvador, Guatemala, Honduras, Nicaragua and Panama, and included representatives of ABET from the U.S. and the Montevideo office of UNESCO. Continuing efforts have resulted in a proposed system of accreditation for the group [27], which could involve 155 public and private universities.

Costa Rica has progressed more independently and implemented an accreditation committee under the auspices of the Colegio Federado de Arquitectos y Ingenieros (CFIA). The Colegio conducted a workshop with inputs from ABET and CEAB personnel [42] and has since adopted the Canadian accreditation model. Two universities now have seven accredited programs. The Consejo Superior Universitario Centroamericano (CSUCA) has been working since 1948 on issues related to regional integration of higher education within the seven nations. The Latin American and Caribbean Consortium of Engineering Institutions (LACCEI) is also working on a regional basis [43].

\section{South America}

Two South American nations, Argentina (Comision Nacional de Evaluacion y Acreditacion Universitaria (CONEAU))[8]; and Colombia (Consejo Nacional de Acreditacion (CNA)) [31], have operational accreditation systems. Two others, Chile through the Comision Nacional de 
Acreditacion (CNA), and Peru through its Instituto para la Calidad en la Acreditacion en las Carreras de Ingenieria y Technologia (ICACIT), have taken steps to implement programs. A number of professional engineers have acted as observers on ABET and CACEI institutional visits. Eight nations have not reported activity and two are dependencies of a European nation. Four have entertained visits by ABET and CEAB personnel.

A project sponsored by the Canadian International Development Agency (CIDA) resulted in special efforts to assist Bolivia, Chile, Colombia and Peru. Heightened interest in accreditation in general is noted by the formation of "Red Iberoamericana para la Acreditacion de la Calidad de la Education Superior" (RIACES). This group includes nine nations of the continent and Spain, presently working on institutional accreditation. Further, the Asociacion Iberoamericana de Instituciones de la Ensenanza de la Inegenieria (ASIBEI) has taken steps to establish criteria for the homogenization, evaluation and accreditation of engineering programs [35].

\section{Caribbean}

Puerto Rico, a Commonwealth of the U.S., participates in the ABET accreditation system. Two nations, Jamaica and Trinidad \& Tobago, have taken steps to plan development of accreditation systems. Nine nations have not reported and there are fourteen dependencies. The Caribbean Council of Engineering Organizations is working with the Caribbean Community of Nations (CARICOM) to develop a regional system [14]. The Latin American and Caribbean Consortium of Engineering Institutions (LACEI) announced a special focus on quality assurance issues [43].

\section{Western Hemisphere}

Summarizing the elements of the regions of the Western Hemisphere we find a total of seven nations with accreditation systems, two are in implementation stages, and eight are in ongoing planning processes. Unfortunately, 17 have given no indication of progress being made. There are 16 dependencies in the hemisphere, which are most likely to pattern themselves after the associated jurisdictions. Significantly, the Western Hemisphere contains about one-third of all the nations in the world with quality assurance systems

\section{Putting Research to Work}

In today's knowledge economy the race is to the creative entrepreneur. However, many companies typically do not have the resources ( e.g. talent, facilities, money, etc.) to carry on

critical research and development independently. On the other hand many universities are in a 
position to produce sophisticated research, thereby adding to the knowledge base and enabling development of commercial products, leading to investments and job creation. Development of university-based Research Parks would ease the transfer of technology from laboratory to the marketplace. Such parks could be a key factor in the promotion of economic development and competitiveness. In the evolving knowledge based economy, the mutual interaction and exchange of intellectual goods and services create an economic model for growth and development. Not all universities should be so engaged, but there should be some centers of excellence in research and development in each country. Further, not all centers should be engaged in the same disciplinary effort, but they should focus their efforts in some manner. The need for a cooperative partnership to coordinate efforts for the benefit of all is apparent.

\section{Indicators}

The search for appropriate indicators to assess the progress toward desired objectives is an essential activity. The United Nations and the World Bank have created sets of indicators to track progress in certain programs. Review of these indicators shows that they are mostly economic, social or health oriented and few such measures have science and/or engineering content. Further, while they may reflect some degree of progress toward desired ends, they reflect little or no cause. Therefore, this suggests that the indicators give little information about cause and effect of the intended development, but represent aggregated results in a way as to not be readily identifiable with pertinent inputs. In the search for engineering excellence in pursuit of economic growth and sustainable development it is believed that indicators should contain factors that are more cause and effect related.

Few direct measures of the science and engineering exist throughout the continent. Therefore, not only is an appropriate data base required, but we must come to terms with proper definitions of the various elements of the science and engineering workforce, and their roles in the conception and creation of new knowledge, products, processes, methods and systems. This information along with appropriate national census data is essential to the formation of appropriate sustainable development indicators.

The context in which we now live (e.g. globalization, rising expectations, capacity building, sustainable development, increasing ethical concerns, quality focus and cultural literacy) all seemingly require better figures of merit. To compete on the global stage, attract investment, and emphasize first-rate centers of design and production in many countries of the hemisphere, requires some indicators that may be interpreted that activities in question have had a beneficial impact. This is essential to the sustainable economic and social development of the hemisphere. 
We conclude that there is a great need for a new class of indicators that will aid public policy determination in this regard..

\section{Associated Education and Accreditation Issues}

The globalization of the marketplace has created a demand for engineering education quality assurance mechanisms. Not only is this important for the provision of potential mobility of practicing professional engineers, it is an essential ingredient in the general technical capacity building of all nations. The harmonizing geopolitical and socio-economical forces at work promote a culture of quality improvement [36] that will benefit all nations. The continuing quest for international recognition of qualifications remains as a forcing function for all of us to continue efforts until we achieve system compatibility, i.e. mutual recognition of international standards. The inability of key players around the world to engage interactively with their counterparts in other nations is an obstacle to the actual attainment of sustainability in mobility in many fields of endeavor related to engineering. With respect to the Western Hemisphere, the question is "why have we for so long ignored the largest market in the world (outside of China and India)," and not forged many North-South linkages. It is interesting to note that the proposed UNESCO Engineering Initiative [46] emphasizes this point..."member states should invite their education institutions and national engineering associations to cooperate closely with UNESCO in its Engineering Initiative through South-South and North-South partnerships.

There are dramatic shifts in opportunity among nations of the world. The idea that the U.S. is the sole driver of economic consumption is rapidly becoming outdated and shortsighted. Recent news items from China indicate that the rural population is agitating for a greater share of the wealth being generated by the rapidly growing Chinese economy. China is drifting toward a consumer-centric society. China's steady climb in developing infrastructure and millions of consumers drive opportunity worldwide. They appear to be concentrating more on their domestic economy. The Western Hemisphere is the largest market worldwide (other than China and India). We are not plagued by any civil conflicts, as are Africa, Asia, and the Middle East. We are not plagued by endless geopolitical debates as is the European Union. We do not have to deal with a plethora of languages as in the European Union (34 at last count vs. 4 in the Americas). Interest in free trade agreements, education and capacity building, and social and economic development abound. National governments, nongovernmental organizations, and multinational corporations are largely shaped by their expertise in and access to intellectual and physical capital in science, technology, and engineering [32]. The extraordinary value of knowledge is that there are no limits to its growth or the value it can generate [56]. 


\section{Future Scenarios}

1. There is wide interest in educational innovation and quality assurance, that is generally viewed as very positive. At the same time there are still many difficulties in reaching common ground necessary for mutual recognition. For example, differing educational systems (length, content, structure, governance and titles), differing systems for granting the right to practice (licensure, registry, education, experience), present problems for existing systems as well as newly developing ones. Alternative education and delivery methods, proliferation of information technology and its rising influence on distance and virtual education. For example, the American Society of Civil Engineers (ASCE) is working to define a Body of Knowledge (BOK) for entry into the practice of civil engineering at the professional level. The premise is that an engineer must possess a much higher degree of cognitive ability that allows application of knowledge to new situations. The suggested ASCE model seeks to strengthen the cognitive ability of engineers and encourages practices that work in cooperation and harmony with the landscape of a project -the environment- for the benefit of society [57].

2. The efforts of the Ministers and High Authorities of Science and Technology within the framework of OAS has led to the call for significant partnerships between industry, government, academia and professional associations dedicated to achieving global leadership and making major economic impacts through enhancing engineering education throughout the Western Hemisphere. Based on the premise that engineering education is the key that promotes capacity building of human resources, education is seen as the driver of expanded economic and social development [39] enabling the flow of people and work across borders. The success of this movement will largely be determined on the resolution of quality assurance mechanisms. Emphasis on 'science' (all aspects of science, technology and engineering) in diplomacy and development policies requires acceleration of the rates of enhancement of engineering education.

3. Accreditation system development has become a major activity. However, the differing cultures, governance systems, degree of institutional autonomy, governmental influence, degree of NGO involvement, peer review by professionals in the discipline, etc. make for a very complex array of constituencies to be satisfied. Outcomes based accreditation criteria have become defacto the international standard for engineering education. Clearly, the attributes (standards) are of necessity changing as we seek better preparation of the those who will practice and carry on. This is the route to enhance quality assurance.

The adaptation of these criteria in many areas (geographical as well as educational) has a significant learning curve. The Engineering Accreditation Commission of ABET needed nearly a decade to fully implement and institutionalize the new outcomes based accreditation criteria. The creation and implementation of new accreditation systems will in most cases require a significant 
change in the culture of the institutions involved and the societies in which they are based. The real challenge is to bring some semblance of order among the 34 nations in the hemisphere, each with its own set of problems, laws and ministries.

4. The rapidly emerging disciplines (e.g. info-, bio-, nano-, etc.) and the blurring of boundaries between disciplines will present many problems for existing quality assurance systems, as well as newly developing ones. The unique characteristics likely to be required of future graduates [22] will create added concerns for accrediting agencies. These issues will only increase in importance as projects become larger in scale and more complex. Clearly, the way in which engineers practice is changing dramatically. Engineering activity will encompass an increasingly broader array of disciplines, posing further difficulties for definition of "engineer." Few engineers will practice with one employer, in one place, in one country in the future. Mobility, flexibility and continuous learning will grow in importance.

5. The US National Academy of Engineering (NAE) report, "Engineer of 2020," utilized a scenario-based planning approach. Admittedly a high-risk but high-pay-off approach [5, 40]. The basic premise was "anticipate the future," then shape engineering education to create a significant dynamic role for the profession. This seminal report focuses attention on the nearly geometric growth rate of engineering knowledge and the accelerating rate of technological introduction and adoption (innovation). Surely, it should be recognized that all nations must be engaged in this process. It must not be assumed that an engineer will know all that needs to be known by the end of the typical undergraduate educational experience. Similar studies by the American Society of Civil Engineers [54], and the American society of Mechanical Engineers [44] also stress the need for changes in engineering education.

6. Science oftentimes is incomplete and engineering thinking has to fill the gap; that's where innovation and entrepreneurship come in to play [52]. "President Wulf of the NAE has stressed the point that reinvigorating innovative capability is the key to future prosperity [47]."

This will be a major challenge inasmuch as the engineering profession seems to have avoided being seen as taking a leadership role in society. However, the profession must focus on innovation; have some understanding of global trends and the economic/societal forces at play. Social, cultural and political forces will shape and affect the success of technological innovation [41]. We must not let the natural world interrupt the advance and benefits of technology being 
shared around the globe. Engineering has a major role to play, both in responsibility for basic infrastructure and also as the keystone for building competitiveness in the global marketplace.

7. Bordogna perhaps said it best, "Engineers are expected to foster progress, toward a daunting array of ends--creating new knowledge, artifacts and systems, stimulating economic development, creating wealth and jobs, sharpening the nation's competitive edge, raising our prospects for more productive and satisfying lives, caring for the environment, and strengthening the national security [4]." These issues are of importance to the entire planet as well as the Western Hemisphere.

8. Achievement of the UN Millennium Goals [51] will require worldwide application of the best engineering talent the collective nations can muster. Every single issue associated with the Millennium Goals depends on engineering: (1) Eradicate extreme poverty and hunger; (2) Achieve universal primary education; (3) Promote gender equality and empower women; (4) Reduce child mortality; (5) Improve maternal health; (6) Combat HIV/AIDS, malaria and other diseases; (7) Ensure environmental sustainability; and (8) Develop a global partnership for development. This framework of eight goals and the related targets and indicators to measure progress toward desired ends is a prime example of diplomacy without 'science' advise. For the most part, proposed indicators have little direct connection to science and engineering, but upon which most surely depend. In short there is a 'new science' required in diplomacy and development [32].

9. To achieve any of the above will require the engineering profession to perfect a greatly enhanced technical expertise combined with creativity and tempered by a sophisticated appreciation of human needs [51]. This view is quite different from the "traditional" concept of an engineer. We should expose our students to more of the concepts of leadership, innovation, entrepreneurship, and diplomacy. The EftA strategy of "job creation" will depend on how adept we are at curriculum development, i.e. engineering education research.

10. Faculty Development is critical. More full-time faculty members will be needed to achieve significant improvements. The productive sector must take a greater interest in the work of the university system, including a willingness to critique higher education. Increased access to graduate study, more time devoted to educational improvement, and enhanced research efforts are essential. 
11. Program and course improvement will depend largely on agreement as to a common 'attributes' derived in quality assurance mechanisms. Access to course /curricular workshops to provide continuing professional development will be essential.

12. Provision of reasonable patrimony laws/rules will enhance funding for development of centers of excellence in selected disciplines. A companion aspect will be greater partnerships between universities and the productive sector. Recognition that the work of higher education is 'productive work' and essential to the well-being of the so-called productive sector.

13. Failure to eliminate the 'brain drain' aspects of study abroad, and the subsequent migration of the brightest simply defeats the effort to greatly enhance the contributions of indigent universities to the social and economic development of their host country. Efforts to create opportunities for returning scholars to make a significant contribution to their sponsoring universities and countries of origin will encourage a 'brain gain.'

14. Greater efforts to generate partnership between universities at home and abroad, between universities and the productive sector, among ministries and key universities to develop centers of excellence, thereby creating centers of innovation, leadership, and entrepreneurial enterprise. The PLAN PANAMA of the Ministers and High Authorities of Science and Technology adds emphasis to the need for science diplomacy.

\section{Why Engineering for the Americas}

International trade, the flow of trade, has from the earliest times shaped and been shaped by history. In 1800 Cubans and the Argentines were richer than North Americans [6]... but the U.S. educated its population, built infrastructure, accumulated capital, mechanized agriculture, etc. and despite a civil war became a global power house. Mexico, one of the first countries in the hemisphere to have a university or a printing press, did not take steps to industrialize. Throughout Latin America, education and the industrial revolution came too late. By 1990 a citizen of Japan produced five times as much wealth as did one in Latin America. Much of the world's new wealth is created by knowledge, but most of the world's population still works in business or endeavors that produce, assemble of sell commodities.

The work of the World Bank (J.D. Wolfensohn) perhaps exemplifies what EftA is trying to achieve. We..." must empower the poor people and the disenfranchised-the people at the 
fringes - and give them a real stake in society". This is the key to building the stronger institutions required for longer term sustainable development. In the current scenario all nations are seeking to maintain and/or create centers of design and production based on education, research and innovation. Engineering is the key to building this capacity. Growth and wealth will be distributed unevenly as long as only a few communities pay attention to their children's science and engineering education and disproportionately attract the world's best brains [7] The World Bank's work in the education arena seems to favor the global market and the individual as the means to develop the knowledge and skills required for the knowledge economy to survive on a sustainable basis.

Simon Ramo in addressing the National Academy of Engineering recognized the very nature of our problem [30], "Either the engineering profession will broaden greatly or the society will suffer because the matching (between society and technology) will be too haphazard"..."a greater engineering needs to evolve,"..." it will become to embrace much more of the issues at the technology-society interface." Finding society's needs and fulfilling them by designing creative solutions has been, and will continue to be an engineer's role in this age of technology and progress [10]. In short, engineers must recapture the leadership reins, not just respond to policy decisions made by others. Successful leaders don't start out by asking "What do I want to do?"...They ask, "What needs to be done?" [16,17]. Should we not develop a few action items with a high priority and get on with the job?

Bernard Amadei, the progenitor of the Engineer Without Borders movement, recounted: "Engineers have an obligation to provide solutions to meet the basic needs of all humans for water, sanitation, food, health and energy, while at the same time protecting the cultural and natural diversity. It is no longer an option, it is an obligation." This is somewhat of a wake up call, as we have always been a serving profession, but in this era, are we in danger of drifting into a mere commodity mode. Nations and even civilizations do not prosper, nor will they even survive very long, if they can't provide the fundamental pillars of a knowledge-based economy [7].

It is well recognized that engineering is at the core of many essential industries and services. The so-called race for the engineering edge will be won or lost in our engineering schools [9]. Our nations are at risk if we leave innovation to others. The failure to produce adequate 'brainpower' in science and engineering will result in failure to gain ground in the global economic competition. The creation of an excellent science and engineering workforce will attract foreign investment. The creation of research centers and first-rate centers of design and production will be attractive to many multinational firms. 


\section{Closure}

The demand for engineering education quality assurance mechanisms is growingg. Not only is this important for the provision of potential for mobility of practicing professional engineers it is an essential ingredient in the general technical capacity building of all nations. The harmonizing geo-political and socio-economical forces at work promote a culture of quality improvement [29] that will benefit all nations. Those in charge of our quality assurance mechanisms must take advantage of the fact that they have a key role to play in this process. It is noted that the First Annual Report of ECPD (forerunner of ABET) identified its aims and objectives as..."to promote efforts and aspirations directed toward the higher professional standards of education and practice, greater solidarity of the profession, and greater effectiveness in dealing with technical, social, and economic problems [53]." The task remains.

There appears to exist a continuing convergence between nations in terms of the requirements for professional practice. The continuing quest for international recognition of qualifications remains as a forcing function for all of us to continue negotiations until we achieve system compatibility, i.e. mutual recognition of international standards throughout the hemisphere. At present, the international standard is seen to be the attributes of the Washington Accord, which is largely based on the work of ABET/EAC and EC/CEAB. The inability of key players to engage interactively with their counterparts in other nations is an obstacle to the actual attainment of sustainability in many fields of endeavor related to engineering and this inability hamper our capacity to serve various elements of our societies.

It is concluded that the "Engineering for the Americas" movement is in the self-interest of all engineers as well as that of all the nations of the hemisphere (regardless of state of development). The activity is viewed as good public policy. The attraction of entrepreneurial investment, and the resulting sustainable economic development of the hemisphere are critical to the welfare of all. The words of Oliver Wendell Holmes contain some good advice: "The great thing in this world is not so much where we stand as in what direction we are moving." We should see northsouth linkages as viable as east-west linkages. The proposed UNESCO Engineering Initiative underscores the wisdom of the EftA concept.

In the late twentieth century the U.S. became aware that partnerships of colleges, businesses, industries, and many other associations formed a web/network of affiliations that were beneficial to all concerned. Now, in the early twenty-first century it is recognized that in the development 
of technological innovation, in education and training, and in opening new markets abroad, public and private sectors are often forming partnerships with a variety of stakeholders. Indeed, partnerships among the productive sector, academia, NGO's and governmental units are now seen as essential pieces in developing competitiveness strategies [12]. This move to broad-based cooperation and collaboration will influence the pace of innovation, investment and economic growth well into the twenty-first century [13]. The plea for regional integration by presidents of several Latin American nations..."we have common roots; we all agree on strengthening our democratic institutions because what is at stake is our future, integration is possible." [50].

\section{References}

[1] Abeu, Alicia. "The Declaration of Lima," Adopted at the fourth plenary session of Ministers and High Authorities of Science and Technology, Organization of American States, Lima. Peru. 12 Nov. 2004.

[2] Alberts, Bruce. “Turkey and Science Academies,” Science, Vol. 333, No. 6051, pp. 1801. 30 Sept. 2011.

[3] Boev, Oleg. "The Development of the National Accreditation for Engineering Education in Russia," ASEE International Colloquium on Engineering Education. Nashville, TN. 20-23 Jun. 2003.

[4] Bordogna, Joseph. "U.S. Engineering Enabling the Nation's Capacity to Perform," The Bent of Tau Beta Pi, V93N4, Fall 2003.

[5] Clough, G. Wayne. “The National Academy of Engineering's Engineer of 2020,” UPADI 2006 Plenary Session on Education, Atlanta, GA. 21 Sept. 2006.

[6] Drosdorf, Daniel. "When Good is not Good Enough, IDB America, Magazine of the Inter-American Development Bank, 13 October 2003.

[7] Enriquez, Juan. As The Future Catches You, Crown Business Publishes, New York, 2001.

[8] Guiardo, Robert Gomez. Initiatives for Accreditation: Argentina. Panamerican Academy of Engineering Policy Forum, Montevideo, Uruguay. 9 Oct. 2003.

[9] Hall, K.G. "The Race for the Engineering Edge to be won or Lost in Colleges," The Denver Post, 15 Aug. 2005.

[10] Hamilton, Janna. "Leadership in Engineering," E-news, Engineers Without Borders Canada.Apr. 2007.

[11] Heitmann, Gunter. "Accreditation and Quality Assurance Threshold Standards and Beyond," ASEE/WFEO International Colloquium, Nashville, TN. 20-23 Jun. 2003.

[12] Hughes, Neal H. "Introduction: Meeting the New Economic Challenge Forging an American Dream for the Twenty-First Century," Building the next American Century: the Past and Future of American Economic Competitiveness, Woodrow Wilson Center Press, Washington, D.C. 2005.

[13] Hurd, Douglas. "Robert Peel: A Biography," The Economist, 30 Jun. 2007.

[14] Imbert, Clement. "Caribbean Engineering Accreditation in a Regional Context," Panamerican Academy of Engineering Policy Forum, Montevideo, Uruguay. 9 Oct. 2003.

[15] Jones, Russel C. "Technical Capacity Building for Economic Development," Panamerican Academy of Engineering Policy Forum, Montevideo, Uruguay, ,9 Oct. 2003.

[16] Kane, Tim, Kim R. Holmes, and Mary Anastasia O'Grady. 2007 Economic Freedom Index, The Heritage Foundation, Washington, D.C. 2007.

[17] Karlgaard, Rich. "Peter Drucker on Leadership," Forbes, 19 Nov. 2004. 
[18] Kersten, Robert D. "Accreditation in a Regional Context Terms of Reference," Panamerican Academy of Engineering Policy Forum, Montevideo, Uruguay. 9 Oct. 2003..

[19] Kersten, Robert D. and George Peterson. "International Recognition of Engineering Qualifications," Proceedings of the 2004 International Colloquium of American Society, Peoples Republic of China, 7-10 Sept. 2004

[20] Kersten, Robert D. Internationalization of Accreditation: An ABET Perspective on the Americas," UPADI 2006 Congress on Engineering Education, Atlanta, GA. 18 Sept. 2006

[21] Lerner, Norman, Internal OAS working documents 2010-11.

[22] McRae, Hamish. “The World in 2020," Keynote address ABET Annual Conference, Minneapolis. MN. 30-31 Oct. 2005.

[23] Marcek, Daniel. "Engineering for the Americas," UPADI 2006 Congress on Engineering Education, Atlanta. GA., 18 Sept. 2006.

[24] Martin, Michaela and Anthony Stella. "External Quality Assurance: Making Choices.” UNESCO 2007.

[25] Miranda, Herbert, Sistema de Evaluacion y Acreditacion de Programas de Ingenieria, Project Report Proyecto BID ATN/SF-7195-RG, Universidad de San Carlos, Guatemala City, Guatemala. Jun. 1998.

[26] Miszalski, Wlodzimierz. "The Spheres and Proportions of Future Engineer's Knowledge as the Startpoint of the Discussion on the Comparability and Mutual Approvals of Engineer Diplomas," ASEE/WFEO International Colloquium, Nashville, TN. 20 Jun. 2003.

[27] Nieto Lovo, Mario R. " Situacion de la Ensenanza de la Ingenieria en la Region Centroamericana y el Esfuerzo de REDICA para la Creacion del Sistema de Evaluacion y Acreditacion de Programas de Ingenieria," Centro Americana Regional Workshop, Studying Capacity Building, Toluca, Mexico. Mar. 2004.

[28] Ocampo, Fernando. "Accreditation in Latin America" ASEE/WFEO International Colloquium, 20-22 Jun. 2005, Nashville, TN.

[29] Peterson, George. "ABET International Activities in the Western Hemisphere," Ibero-American Summit on Engineering Education, Sao Paulo, Brazil. 24 Mar. 2003.

[30] Ramo, Simon. discussion at National Academy of Engineering Symposium

[31] Revelo. Jose R. "Initiatives for Accreditation in Columbia." Panamerican Academy of Engineering Policy Forum, Montevideo, Uruguay. 9 Oct. 2003.

[32] Reynolds, Andrew. "Science, Technology and Engineering Education In $21^{\text {st }}$ Century Diplomacy and Development," LINC 2010 Conference, MIT Cambridge, MA, 23-26 May 2010

[33] Robertson, Susan L. "Re-Imagining and Rescripting the Future of Education: Global Knowledge Economy Discourses and the Challenge to Education Systems," Comparative Education, 2 May 2004

[34] Rowe, Debra. "Education for a Sustainable Future,” Science Vol. 317, 20 July 2007.

[35] Salazar Contreras, Jaime. Report of the Executive Director-ASIBEI,” 2005. Bogota, Colombia.

[36] Salmond, MP, Alex. "Forbes on Innovation,” Forbes, Vol. 188 No. 6, 10 Oct. 2011.

[37] Santamaria Siurana, Cristina; Jacaoo Navarro; Vincente Cloquell Ballesterl. "Global Accreditation Trends in Engineering Education," 1-4 Oct. 2002, Berlin, Germany.

[38] Scavarda, Louiz Carlos. "Global Approach to the Quality in Engineering Services," Panamericaan Academy of Engineering Policy Forum. 9-10 Oct. 2003, Montevideo, Uruguay.

[39[ Scavarda, Luiz. "Engineering for the Americas: Human Resources for Technology Based social Development," International Conference on Engineering Education, 24-28 July 2006, San Juan, Puerto Rico.

[40] Schwartz, Peter "Extremely Well Educated Guesses," (A futurist scenario planner) 2004.

[41] Schwartz, Peter. "Future Shock If you thought the past 50 years were a time of radical change, you ain't seen nothing" Fortune, 5 Apr. 2004. 
[42] Trejos, Roberto. "Sistema Estadounidense de Acreditacion," Keynote address, Taller de Acreditacion de Carreras De Ingenieria y Arquitectura, ColegioFederado de Ingenieros y Arquitectos de Costa Rica. 2-4 Sept. 1999.

[43] Velez-Arocho, Jorge. Remarks at Strategic Planning Session of EftA. 26 July 2006.

[44] Wepfer, William and R. O. Warrington. "Vision 2030: Creating the Future of Mechanical Engineering Education," American Society of Mechanical Engineers, 7 Jun. 2010, Pittsburgh.

[45] Wolfe, Deborah. "Initiatives for Accreditation in the Continent: Canada," Panamerican Academy of Engineering Policy Forum, 9-10 Oct. 2003, Montevideo, Uruguay.

[46] Woodward, Eric W. Commentary on UNESCO activities, U.S. National Commission for UNESCO, Department of State, 1 Nov. 2011.

[47] Wulf. William. "Changes in Innovation Ecology," Science, Vol. 316, No. 5829, p. 1253, 1 June 2007

[48] Yeargan, Jerry. "Current Status of Accreditation in Engineering Education," Ibero-American Summit on Engineering Education, 24-27 Mar. 2003, Sao Paulo, Brazil

[49] Yeargan, Jerry. "Initiatives for Accreditation in the Continent: Western Hemisphere Partnership," Panamerican Academy of Engineering Policy Forum, 9-10 Oct. 2003, Montevideo, Uruguay.

[50] Zopf, Yann. World Economic Forum Infomedia, * April 2010, Cartagena, Colombia

[51]___ The UN Millennium Goals Development Report, World Summit at UN Headquarters, 14-16 Sept. 2005, New York, New York.

[52] __Leading the way to Excellence, Robert R. McCormick School of Engineering and Applied Science, Northwestern Engineering, Evanston, Illinois, Spring 2007.

[53] __ First Annual Report of the Engineers' Council for Professional Development, 10 Oct. 1933, New York, N.Y.

[54] __ The Vision for Civil engineering in 2025: A Roadmap for thee Profession, American Society of Civil Engineers Task Force, Aug. 2009, Reston, Virginia.

[55] _ "Accelerating Catch-up: Tertiary Education for Growth in Sub-Saharan Africa.” World Bank, 7 Oct.

[56] Federoff, Nina V. “The Global Knowledge Society,” Science. Vol. 335, 3 Feb. 2012.

[57] Schexnaydar, Clifford and E.J. Jaselskis. "Awareness of Landscape and Ability to Think," Tenth LACCEI Latin American and Caribbean Conference for Engineering and Technology, 23-27 July 2012, Panama City, Panama.

$* * * * * *$

1.WHITE PAPER prepared by members of the Committee on Engineering Education of the Pan American Union of Engineering Associations (UPADI), for use by the Delegates and High Authorities at the UPADI XXXIII Congress, to be held in Havana, Cuba 8-12 April 2012. The primary focus of the Education Symposium is on the Engineering for the Americas (EftA) initiative.

2. Members of the AAES IntAC Task Force on UPADI and contributors to this WHIE PAPER:

Dr. Robert Kersten, Dean \& Professor Emeritus, University of Central Florida, rdk99@earthlink.net

Dr. Robert Warrington, Dean Emeritus \& Director Inst. For Interdisciplinary Studies, Michigan Tech. Univ. row@mtu.edu

Dr. Raymond Issa, Dir. Graduate \& Distance Education Programs, University of Florida, raymond-issa@ufl.edu

Dr. Reginald Vachon, UPADI Vice President North America, Chair AAES IntAC, rvachon@ directmeasure.com

Dr, Norman Lerner, Ex-Sr. Advisor CITEL/OAS Interamerican Telecom. Commission, nclerner@alum.mit.edu

Dr. Luiz Carlos Scavarda, Vice President Pontificia Universidad Catolica, Rio De Janeiro, scavarda@puc-rio.br

Dr. Clifford Schexnaydar, Eminent Scholar Emeritus, Arizona State University, cliff.s@asu.edu

(Comments will be welcome. Please address any of the above with a copy to the Senior Author.) 


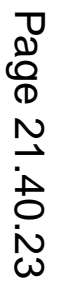

